\title{
PERBANDINGAN TAFSIR TULIS DAN LISAN M. QURAISH SHIHAB TENTANG QS. AL-QALAM DALAM TAFSIR AL-MISBAH (Analisis Ciri Kelisanan Aditif Alih-Alih Subordinatif)
}

\author{
Muh Alwi HS \\ Universitas Islam Negeri Sunan Kalijaga Yogyakarta \\ Mubalwibs2@gmail.com \\ Diterima 24 Mei 2019 | Direview 30 Mei 2019 | Diterbitkan 27 Juni 2019
}

\begin{abstract}
:
This paper would like to present in a comparative analysis the interpretation made by M. Quraish Shibab about QS. al-Qalam. Comparison of interpretations in this paper will elevate the written and oral interpretation of M. Quraish Shibab at once, in this case the interpretation of writing will refer to the Tafseer of Al-Misbah, and the interpretation of the Oral will refer to the "Kajian Tafseer of Al-Misbah". What is interesting in the interpretation of M. Quraish Shibab is that even though it is done by the same person, there is a difference between the interpretation of the text and the oral interpretation of M. Quraish Shibab. The process of comparison of interpretations will be analyzed using the theory of orality, especially additive traits instead of subordinates. The question to be answered in this paper is how are the differences and similarities between M. Quraish Shihab's written and oral interpretations of surah al-Qalam? What causes these differences and similarities?
\end{abstract}

Keywords: M. Quraish Shibab, Tafseer of Al-Misbah, Oral Interpretation

\begin{abstract}
Abstrak:
Makalah ini ingin menyajikan dalam analisis komparatif interpretasi yang dibuat oleh M. Quraish Shibab tentang QS. alQalam. Perbandingan interpretasi dalam makalah ini akan meningkatkan interpretasi tertulis dan lisan dari M. Quraish Shibab sekaligus, dalam hal ini interpretasi tulisan akan merujuk kepada Tafsir Al-Misbah, dan interpretasi Lisan akan merujuk pada "Kajian Tafsir Al-Misbab". Yang menarik dalam penafsiran M. Quraish Shibab adalab babwa meskipun dilakukan oleh orang yang sama, ada perbedaan antara penafsiran teks dan penafsiran lisan dari M. Quraish Shihab. Proses perbandingan interpretasi akan dianalisis menggunakan teori orality, terutama sifat-sifat aditif alih-alih bawahan. Pertanyaan yang harus dijawab dalam makalah ini adalah bagaimana perbedaan dan persamaan antara interpretasi tertulis dan lisan $M$. Quraish Shihab dari surah al-Qalam? Apa yang menyebabkan perbedaan dan persamaan ini?
\end{abstract}

Kata-Kunci: M. Quraish Shibab, Tafsir Al-Misbah, Tafsir Lisan

\section{Pendahuluan}

Kegiatan menafsirkan a-Qur'an, baik itu berada pada tafsir sebagai proses maupun tafsir yang nantinya akan menjadi produk, ${ }^{1}$ dapat dilakukan dengan penafsiran secara lisan dan tulisan. Penafsiran secara lisan dilakukan dengan menyampaikan makna dan kandungan al-Qur'an dengan pengucapan langsung kepada audien (pendengar). Penafsiran secara lisan ini sebenarnya telah dilakukan oleh Nabi Muhammad sendiri, hal ini dapat diketahui dari berbagai penjelasan yang dilakukan oleh Nabi tentang kandungan al-Qur'an yang tidak (atau sulit) dipahami oleh sahabat. ${ }^{2}$

\footnotetext{
${ }^{1}$ Lihat penjelasan lebih jauh dalam Abdul Mustaqim, Pergeseran Epistemologi Tafsir. (Yogyakarta: PT LKiS Printing Cemerlang, 2011), h. 32.

${ }^{2}$ Seringkali Nabi menjadi Mubayyin, yakni penjelas atas permasalahan yang dihadapi umat, lihat lebih jauh Imam Musbikin, “Mutiara” Al-Qur'an, khazanah Ilmu Tafsir dan Al-Qur'an, (Madiun: Jaya Star Nine, 2014), h. 5-6. Di sana dikatakan bahwa Nabi menjadi mufassir pertama. Contoh penafsiran lisan yang dilakukan oleh Nabi, dapat dilihat ketika beliau membahas tentang QS. al-Baqarah: 187, yakni tali putih dari tali hitam, Nabi menjelaskannya sebagai cahaya siang/fajar dan kegelapan malam. Penjelasan Nabi seperti ini disebut ta'rif, yakni penegasan at as ayat al-Qur'a. Penafsiran Ini juga merupakan satu dari banyak ragam penafsiran secara oral yang dilakukan oleh Nabi, liha selengkapnya M. Quraish Shihab, Kaidah Tafsir, (Tangerang: Penerbit Lentera Hati, 2015), h. 358-359.
} 
Sementara itu, penafsiran tulisan dilakukan dengan membuka makna dan kandungan al-Qur'an yang dituangkan dalam bentuk tulisan. penafsiran seperti ini telah banyak dilakukan baik di kalangan sahabat, maupun oleh ulama-ulama sepanjang sejarah, baik pada era klasik, pertengahan, maupun pada era modern-kontemporer. ${ }^{3}$ Berkenaan dengan ini, Quraish Shihab mengemukakan bahwa tidak jarang sahabat tidak hanya menulis al-Qur'an, akan tetapi juga memberinya penjelasan tentang maksud dari ayat al-Qur'an itu, sekalipun pada saat itu tradisi tulis masih tergolong langka. ${ }^{4}$

Selanjutnya, perkembangan dan kemajuan teknologi sangat memengaruhi dunia penafsiran. Di antaranya, terciptanya media (audio, video, media televisi, dan lain sebagainya) yang mampu merekam penafsiran seseorang. Menurut Mark Slouka -sebagaimana dikutip Ardhie Raditya- bahwa media senantiasa mempengaruhi kehidupan masyarakat, ${ }^{5}$ sehingga media senantiasa menjadi pilihan yang memadai dalam menyebarkan ajaran Islam (baca: kandungan al-Qur'an).

Dalam konteks Indonesia, M. Quraish Shihab merupakan tokoh penafsir terkemuka yang sangat berpengaruh, tidak hanya berkisar pada karya kitab tafsirnya (Tafsir Al-Misbab), tetapi juga pada penafsiran yang dilakukannya secara lisan, hal ini bisa dibuktikan di mana beliau selalu memberikan ceramah di berbagai forum, baik yang ditayangkan di televisi maupun yang tidak. Bahkan M. Quraish Shihab memiliki kajian khusus, yakni "Kajian Tafsir Al-Misbah" di stasiun MetroTV. Selain itu, M. Quraish Shihab juga termasuk ulama dan intelektual yang mudah dipahami dalam menyampaikan penafsirannya. ${ }^{6}$ Lebih jauh, selain dengan bahasanya yang mudah dipahami untuk orang awam, kandungan penjelasannya dapat berskala terpelajar. ${ }^{7}$

Lebih jauh lagi, M. Quraish Shihab dikenal sebagai cendikiawan, tokoh ulama, serta penafsir yang mampu menyelaraskan konteks masa kini dengan kandungan al-Qur'an yang disampaikannya. ${ }^{8}$ Baik dalam kitab tafsir Al-Mishbah-nya, maupun dalam penyampaian ceramahnya. Yang demikian itu sebagaimana disanjungkan oleh Pengantar Redaksi Kompas bahwa "Menyejukkan. Ini kesan yang timbul saat membaca tulisannya tentang berbagai persoalan kemasyarakan dan keagamaan. Begitu pula bila mendengar ceramahnya."

Dari kenyataan di atas, penulis kemudian hendak melakukan penelitian tentang penafsiran yang dilakukan oleh M. Quraish Shihab secara tertulis dan lisan. Penafsiran secara tertulis yang dimaksud di sini adalah, penafsiran M. Quraish Shihab di dalam kitab tafsir AlMisbah. Sementara penafsiran M. Quraish Shihab, penulis akan merujuk kepada ceramah M. Quraish Shihab dalam "Kajian Tafsir Al-Misbah" yang disiarkan di MetroTV pada tahun 2005. Penelitian ini akan menfokuskan pada kajian tentang QS. al-Qalam, Bagi Quraish Shihab surah al-Qalam merupakan surah yang berperan penting dalam kehidupan M.

\footnotetext{
${ }^{3}$ Misalnya penafsiran yang terdapat dalam mushaf 'Aisyah tentang QS. al-Baqarah: 238, sebagaimana yang

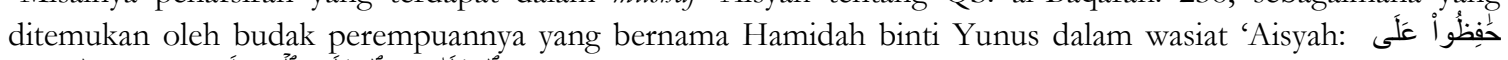

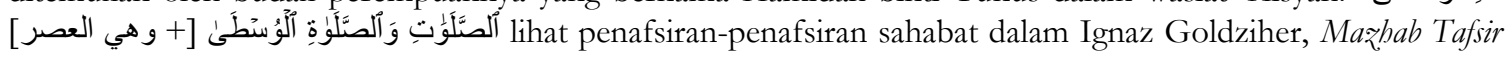
dari Klasik hingga Modern, terj. M. Alaika Salamullah, dkk, (Yogyakarta: Penerbit eLSAQ Press, 2010), h. 25.

${ }^{4}$ M. Quraish Shihab, Membumikan al-Qur'an: Memfungsikan Wabyu dalam Kebidupan. (Tangerang: Lentera Hati, 2011), h. 570.

${ }^{5}$ Ardhie Raditya, Sosiologi Tubuh: Membentang Teori di Ranah Aplikasi. (Yogyakarta: Kaukaba Dipantara, 2014), h. 218.

${ }^{6}$ Mahfudz Masduki, Tafsir Al-Mishbah M. Quraish Shibab: Kajian atas Amtsal al-Qur'an. (Yogyakarta: Pustaka Pelajar, 2012), h. 13.

${ }^{7}$ Lihat Howard M. Federspiel, Kajian Al-Qur'an di Indonesia, terj. Tajul Arifin. (Bandung: Penerbit Mizan, 1996), h. 298.

${ }^{8}$ Abd. Mufid, "Perbandingan Kerajaan Allah menurut Stephen Tong dan Al-Mulk Menurut M. Quraish Shihab", Skripsi UIN Sunan Kalijaga Yogyakarta, 2012, h. 94.

${ }^{9}$ M. Quraish Shihab, Wawasan al-Qur'an: Tafsir Maudbui atas Pelbagai Persoalan Umat. (Bandung: Penerbit Mizan, 1996), h. v.
} 
Quraish Shihab. Penafsir kontemporer ini terinspirasi oleh surah yang diawali dengan huruf Nun ini. ${ }^{10}$ Lebih jauh, dalam surah al-Qalam disebutkan Nun, wal-qalami wa ma yasturun (Nun, demi pena dan apa yang mereka tulis), ayat tersebut menjadi landasan harapan Quraish Shihab untuk anak-anaknya -bahkan keluarga cucu-cucunya, ia berkata "saya berharap bahwa dengan memulai huruf nun, insyaAllah anak-anak saya menjadi ilmuan...,

Selanjutnya dalam penafsirannya, terjadi perkembangan atau perubahan makna dalam penafsiran Quraish Shihab dari yang dicantumkannya di dalam penafsiran tulisannya -dalam hal ini adalah kitab tafsir Al-Misbah- dengan penafsiran yang dilakukannya dengan ceramah dalam kajian Tafsir Al-Mishbah di Metro TV. Ini bisa dilihat -misalnya- ketika Quraish Shihab menafsirkan makna sujud (lihat ayat 43 dari surah al-Qalam), pada penafsiran tertulisnya, ia tidak banyak menjelaskan makna kata tersebut, melainkan hanya sujud -bagian dari gerakan dalam shalat. ${ }^{12}$ Akan tetapi, makna sujud yang disampaikan Quraish Shihab dalam bentuk lisan dibagi menjadi tiga, yakni ${ }^{13}$ (1) sujud bermakna yang menjadi bagian shalat, (2) sujud bermakna shalat -karena sujud sebagai gerakan inti dari shalat, dan (3) sujud bermakna kepatuhan secara umum kepada Allah. Dari sini kemudian menarik untuk dikemukakan lebih jauh tentang perbandingan penafsiran tulisan dan lisan Quraish Shihab. Dalam perbandingan tersebut akan dilihat bagaimana wacana lisan dan tulisan berpengaruh pada transmisi penafsiran Quraish Shihab dari teks ke lisan.

\section{Metode dan Teori}

Penelitian ini merupakan jenis penelitian kepustakaan, yakni penelitian yang dilakukan dengan fokus pada penelusuran sumber-sumber yang berkaitan dengan tema, kitab Tafsir alMisbah dan "Kajian Tafsir al-Misbah" menjadi data primer penelitian ini, khususnya yang membahas surah al-Qalam. Untuk analisisnya, penulis menggunakan metode kualitatif, yakni metode yang terfokus pada analisis data yang ada. Adapun pendekatan yang digunakan dalam penelitian ini adalah pendekatan deskriptif-analitik, yakni pendekatan yang menyajikan sekaligus menganalisis data-data secara sistematik, sehingga mencapai kesimpulan yang jelas.

Selanjutnya, teori yang digunakan dalam menganalisis penafsiran Quraish Shihab adalah teori Kelisanan dan Keaksaraan dari Walter J. Ong, yang dalam hal ini akan difokuskan pada ciri kelisanan aditif alib-alib subordinatif, yakni dalam sebuah penyampaian, struktur tulisan cenderung memerhatikan aturan dalam membuat kalimat (sintaksis). Namun ketika kalimat itu disampaikan dalam bentuk lisan, maka struktur yang dibangun oleh budaya lisan senantiasa berdasarkan kehendak orang yang berbicara. ${ }^{14}$

\section{Quraish Shihab dan Karya-Karyanya}

Nama M. Quraish Shihab tidaklah asing bagi pengkaji al-Qur'an. Ia merupakan seorang mufassir kontemporer di Indonesia. Berbagai peran penting telah dilaluinya, misalnya menjadi rektor IAIN Syarif Hidayatullah Jakarta pada tahun 1992-1998, Ketua Majelis Ulama Indonesia (Pusat) pada tahun 1985-1998, anggota MPR-RI pada tahun 19821987 dan 1987-2002, sampai menjadi Mentri Agama Republik Indonesia pada tahun $1998 .{ }^{15}$

\footnotetext{
${ }^{10}$ Huruf Nun dari surah al-Qalam oleh Quraish Shihab dijadikan huruf pertama untuk semua anak perempuannya (yakni Najla, Najwa, Nasywa, dan Nahla).

${ }^{11}$ Lihat video rekaman "Shihab dan Shihab" episode kedua, dipublikasikan oleh Roney 118 pada tanggal 29 Juni 2017. Menit 02:39-02:50.

${ }^{12}$ Lihat M. Quraish Shihab, Tafsir Al-Mishbah: Pesan, Kesan, dan Keserasian al-Qur'an, Vol XIV, h. 396.

${ }^{13}$ Video rekaman Quraish Shihab tentang penafsiran surah al-Qalam ayat 33-43, dalam "Kajian Tafsir AlMishbah" Metro TV, pada 13 Oktober 2005. Menit 19:12-22:54.

${ }^{14}$ Walter J. Ong, Kelisanan dan Keaksaan, terj. Rika Iffati. (Yogyakarta: Penerbit Gading, 2013), h. 57.

${ }^{15}$ M. Quraish Shihab, Secercah Cahaya Ilahi: Hidup Bersama Al-Qur'an. (Bandung: Penerbit Misan, 2013), h. 5-6.
} 
Nama direktur Pusat Studi Al-Qur'an ini bahkan tercantum sebagai salah satu tokoh ulama yang berpengaruh di dunia, yakni 500 muslim paling berpengaruh di dunia. ${ }^{16}$ Semua ini seakan menjadi bukti dari nasehat Ayahnya yang mengatakan "Kalau kamu tidak bisa menyamai orang lain, (maka) lebibi dia! ${ }^{17}$.

M. Quraish Shihab lahir pada 16 Februari 1944, di Rappang, Kabupaten Sidenreng Rappang, Sulawesi Selatan, ${ }^{18}$ Ia termasuk keluarga yang mempunyai garis keturunan Arab Quraish, yakni Bugis yang terpelajar. ${ }^{19}$ Sejak kecil ia telah akrab dengan al-Qur'an, Ayahnya selalu mengikutkannya dalam pengajian al-Qur'an yang diadakannya, selain menyuruhnya membaca al-Qur'an. ${ }^{20}$ Bahkan sejak umur 6-7 tahun, ia telah sering didengarkan kisah-kisah dalam al-Qur'an oleh Ayahnya. Inilah yang menyebabkan ia sangat berminat untuk mengkaji dan mendalami al-Qur'an. ${ }^{21}$ Selain itu, pengaruh keluarga dan lingkungan semasa kecilnya sangat membimbingnya dalam mengembangkan pengetahuannya, ayahnya yang merupakan seorang ulama dan guru besar dalam bidang tafsir berperan penting dalam kehidupan M. Quraish Shihab. ${ }^{22}$

Selain ayahnya, ibunya juga berperan penting dalam perkembangan keilmuannya. Namun, berbagai referensi nampaknya tidak menjelaskan secara spesifik bagaimana peran penting sang ibu kepada Quraish Shihab. Tetapi, hal ini bukan berarti peran ayah lebih besar dibandingkan ibu. Quraish Shihab sendiri mengatakan bahwa peran penting dari orang tua tidak harus dalam bentuk mengajar, tetapi memberikan contoh yang positif juga sebagai pendidikan untuk anaknya. ${ }^{23}$ Berkenaan dengan ini, ibu Quraish Shihab nampaknya lebih banyak memberikan contoh dalam kehidupan mufassir kontemporer ini.

Sekolah dasar Quraish Shihab diselesaikan di Makassar, setelah itu ia melanjutkan studinya di Pondok Pesantren Darul Hadis | Al-Faqbiyah, Malang. Belum selesai di pesantren tersebut, pada tahun 1958 M. Quraish Shihab pindah ke sekolah Tsanawiyah Al-Azhar, dan dilanjutkannya pada jenjang SMA di negeri Piramida itu. Pada tahun 1967 ia berhasil mendapat gelar Lc, yang kemudian disusul gelar M.A. pada tahun 1696 dengan jurusan yang sama. Selanjutnya, tahun 1982 M. Quraish Shihab akhrinya merai gelar Doktornya dalam bidang ilmu al-Qur'an. ${ }^{24}$ Perjalanan pendidikannya tersebut ini -menurut Howard M. Federspiel- menjadikannya unik dan terdidik dengan baik. Hal ini disebabkan pada saat itu, untuk pendidikan setingkat demikian, biasanya dicapai di Barat. ${ }^{25}$

M. Quraish Shihab dikenal sebagai cendikiawan, tokoh ulama, serta mufassir yang mampu menyelaraskan konteks masa kini dengan kandungan al-Qur'an yang

\footnotetext{
${ }^{16}$ Https://id.wikipedia.org/wiki/Muhammad_Quraish_Shihab. Lebih_ jauh lihat situs http://themuslim500.com. Diakses pada 28 September 2017.

${ }^{17}$ Hal ini berkenaang dengan bahasan siri', istilah budaya masyarakat Bugis-Makassar, yang disampaikan oleh M. Quraish Shihab dalam Tafsir Al Mishbah spesial Idul Fitri. Bersama Prof. Quraish Shihab dan Wakil Presiden Republik Indonesia Jusuf Kalla. Dalam Kajian Tafsir Al-Mishbah Spesial Hilbram Dunar -Jusuf Kalla, MetroTV. Diakses pada 27 September 2017. Menit 23:08-23:19.

${ }^{18}$ M. Quraish Shihab, Membumikan al-Qur'an: Fungsi dan Peran Wahyu dalam Kehidupan Masyarakat. (Bandung: Penerbit Mizan, 1995), h. vii.

${ }^{19}$ https://id.wikipedia.org/wiki/Muhammad_Quraish_Shihab. Diakses pada 28 September 2017.

${ }^{20}$ https://id.wikipedia.org/wiki/Muhammad_Quraish_Shihab. Diakses pada 28 September 2017.

${ }^{21}$ Muaddibi Asfiyak R, “Hermeneutika Al-Qur'an M. Quraish Shihab dalam Tafsir Al-Mishbah”, Skripsi UIN Sunan Kalijaga Yogyakarta, 2017, h. 28.

${ }^{22}$ https://id.wikipedia.org/wiki/Muhammad_Quraish_Shihab. Diakses pada 28 September 2017.

${ }^{23}$ Hal ini sebagaimana disampaikan Quraish Shihab dalam acara "Highlight Mata Najwa: Cerita Dua Sahabat- Bagian 2”. MetroTVnews. Pada 29 Juni 2017. Menit 19:30-19:53.

${ }^{24}$ Muhammad Yusuf Sidik, "Penafsiran Ayat-ayat yang Dimaknai Hubungan Seksual Suami Istri menurut M. Quraish Shihab dalam Tafsir Al-Mishbah", Skripsi UIN Sunan Kalijaga 2016, h. 25.

${ }^{25}$ Howard M. Federspiel, Kajian Al-Qur'an di Indonesia, terj. Tajul Arifin, h. 294.
} 
disampaikannya. ${ }^{26}$ Baik dalam kitab tafsir Al-Mishbah-nya, maupun dalam penyampaian ceramahnya. Hal ini sebagaimana disanjungkan oleh Pengantar Redaksi Kompas bahwa "Menyejukkan. Ini kesan yang timbul saat membaca tulisannya tentang berbagai persoalan kemasyarakan dan keagamaan. Begitu pula bila mendengar ceramahnya." ${ }^{27}$

Adapun karya-karya tulis M. Quraish Shihab di antaranya adalah Tafsir Al-Mishbah; Pesan, Kesan, dan Keserasian al-Qur'an (2003), Tafsir Al-Manar, Keistimewaan dan Kelemahannya (1984), Menyingkap Tabir Ilabi; Asma al-Husna dalam Perspektif al-Qur'an (1998), Untaian Permata Buat Anakku (1998), Pengantin al-Qur'an (1999), Haji Bersama Quraish Shibab (1999), Sabur Bersama Quraish Shibab (1999), Panduan Puasa bersama Qurasih Shibab (2000), Panduan Shalat bersama Quraish Shibab (2003), Anda Bertanya, Quraish Shibab Menjawab Berbagai Masalah Keislaman, Fatwa-fatwa M. Quraish Shihab Seputar Ibadah Mabdah (1999), Fatwa-fatwa M. Quraish Shibab Seputar Ibadah dan Muamalah (1999), Fatwa-fatwa M. Quraish Shihab Seputar al-Qur'an dan Hadits, Studi Kritis Tafsir al-Manar (1996), Lentera Hati; Kisah dan Hikmah Kebidupan (1994), Membumikan al-Qur'an; Fungsi dan Kedudukan Wabyu dalam Kebidupan Masyarakat (1994), Wawasan al-Qur'an; Tafsir Maudbu'i atas Perlbagai Persoalan Umat (1996), Secercah Cabaya Ilahi; Hidup bersama al-Qur'an (1999), dan lain sebagainya.

Selain aktif menulis, M. Quraish Shihab juga aktif dalam mengisi ceramah Islami di berbagai tempat. Bahkan ia aktif dalam beberapa program agama islami di televis, di antaranya:

a. "Kajian Tafsir Al-Mishbah" di MetroTV

b. Kultum di RCTI

c. Hikmah Fajar di RCTI

Melalui program-program tersebut, Quraish Shihab menyampaikan ceramah singkatnya, dengan mengkaji al-Qur'an secara tematik. ${ }^{28}$ Selain tampil di dunia pentelevisian, M. Quraish Shihab juga aktif di Sosial Media, ini bisa dilihat di antaranya dalam Instagramnya dengan nama akun $M$. Quraish Shibab. Dalam akun instagram tersebut selalu mengiringi ungkapan "Semua Guru Semua Murid" yang memberi isyarat bahwa ilmu dapat diperoleh dari siapapun (dan apapun). Hal ini terbukti dalam berbagai video pendek yang termuat dalam akun tersebut tentang diskusi dilakukan oleh anak (Najelaa Shihab) dan ayah sendiri (Quraish Shihab). Selain itu, "Shihab dan Shihab" juga merupakan akun yang menjadi ruang Quraish Shihab dalam menyampaikan ceramahnya. Akun tersebut diketahui disiarkan dibeberapa sosial media, di antaranya Facebook, Instagram, dan Youtube.

Di antara semua karya-karya M. Quraish Shihab tersebut di atas, kitab Tafsir AlMishbah merupakan kitab tafsir yang paling besar dan menjadi kitab fenomenal dalam dunia penafsiran, terutama pada era modern-kontemporer. Model kitab tersebut senantiasa menghidangkan setiap surah, sehingga orang mampu memahami dengan mudah tentang tema atau bahasan yang terkandung dalam surah tersebut. ${ }^{29}$ Selanjutnya, berbagai karya tulis Quraish Shihab - menurut Kusmana sebagaimana dikutip Muzayyin- memperlihatkan karakteristik pemikiran Quraish Shihab yang bersifat rasional dan moderat. Lebih lanjut, bahwa kerasionalannya tersebut bukan sebagai alat untuk memaksakan ajaran agama untuk tunduk kepada realitas, melainkan mencoba menjelaskan khazanah agama yang bersifat

\footnotetext{
${ }^{26}$ Abd. Mufid, "Perbandingan Kerajaan Allah Menurut Stephen Tong dan Al-Mulk Menurut M. Quraish Shihab", Skripsi UIN Sunan Kalijaga, 2012, h. 94.

${ }^{27}$ M. Quraish Shihab, Wawasan al-Qur'an: Tafsir Maudhui atas Pelbagai Persoalan Umat, h. v.

${ }^{28}$ Munirul Ikhwan, “An Indonesian Initiative to Make the Qur'an Down-to-Earth: Muhammad Quraish Shihab and His School of Exegesis", Dissertation, Universität Berlin, Berlin. 2015. h. 14.

${ }^{29}$ Islah Gusmian, Khazanah Tafsir Indonesia: dari Hermeneutika hingga Ideologi. (Jakarta: Teraju, 2003), h. 237.
} 
klasik untuk dipahami secara rasional dalam konteks kontemporer, sehingga tetap mengapresiasi pemahaman yang lama sembari memberikan pemahaman yang baru. ${ }^{30}$

Lebih jauh, berikut adalah ciri-ciri dari pemikiran Quraish Shihab dalam karya-karya tulisnya, sebagaimana yang ditulis oleh Ahmad Wajiz Zamany, sebagai berikut: ${ }^{31}$

1. Memberikan penekanan atas makna kosa kata ayat, serta mengemukakan pandangan para ahli, terutama dalam bidang kebahasaan.

2. Memberikan penekanan atas munasabah ayat dengan ayat lain, atau surah dengan surah lain.

3. Memanfaatkan nalar akal secara luas dalam memahami kandungan al-Qur'an.

4. Senantiasa membuka pintu dialog kepada orang-orang yang tidak puas dengan pemikirannya, karena itu Quraish shihab tidak menyenangi orang yang taqlid buta.

5. Senantiasa menggunakan corak al-Adabi al-Ijmali, yakni berusahan menyinggung persoalan-persoalan sosial.

6. Seringkali menggunakan kaidah-kaidah kebahasaan ketika menafsirkan kandungan alQur'an.

\section{Perbandingan Penafsiran tentang QS. al-Qalam}

Sebelum melakukan perbandingan, perlu ditekankan bahwa pembagian penafsiran tulisan Quraish Shihab berbeda dengan penafsiran lisannya. Karena itu, untuk mempermudah perbandingan penulis di sini akan mengikuti pembagian penafsiran lisan Quraish Shihab yang disampaikan dalam "Kajian Tafsir Al-Misbah" di MetroTV, yakni dibagi atas lima bagian. Hal ini dilakukan mengingat pengaturan terhadap urutan penafsiran tulisan Quraish Shihab lebih mudah dan dapat mengikuti pembagian penafsiran lisan Quraish Shihab, tetapi sebaliknya tidak dapat dilakukan. Adapun perbandingan penafsirannya adalah sebagai berikut:

\section{Perbedaan Penafsiran M. Quraish Shhab}

1) Penafsiran QS. al-Qalam ayat 1-7

Pada ayat ketujuh, Quraish Shihab dalam penafsiran lisannya mengemukakan bahasan tentang rabb dan huwa yang tidak diungkap pada penafsiran tulisannya. mengenai penjelasannya kata rabb tersebut adalah sebagai berikut:

Saya ingin rinci sedikit ayat ini, kalau kita memperhatikan wahyu-wahyu pertama yang turun tidak ada yang disebut kata Allah. Iqra' bismi rabbik di sini Inna rabbaka bukan dia katakan Innallaba, Ya ayyuhal-muddas $\mid$ s $\mid$ ir kum faanz| ir wa rabbaka tidak digunakan kata Allah, kenapa itu? karena kaum musyrik orang kafir pun percaya Allah, tapi Allah yang mereka percayai itu sifatnya berbeda dengan Allah yang dipercayai dengan Nabi Muhammad tetapi Allah yang mereka percayai sifat-sifatnya berbeda dengan yang kita percayai kalau al-Qur'an sejak semula berkata Iqra' bismillah bacalah dengan nama Allah, mereka berkata saya juga kan baca dengan nama Allah, tidak! baca dengan nama Tuhanmu! bukan Tuhan yang mereka sembah!, Tuhan yang pelihara kamu Iqra' bismi rabbik di sini apa Inna rabbaka Tuhan yang pelihara kamu, baru dia katakan Inna rabbaka bua bi-mandalla ansabilibi, mestinya kalau kita lihat terjemahannya ya bu ya sesungguhnya Tuhanmu lebih mengetahui tapi di sini dia tidak katakan begitu sesungguhnya Tuhanmu dia lebih mengetahui, ini kata Dia perlu apa tidak? ini coba saya ulangi sesungguhnya Dia lebih mengetahui, yang kedua sesungguhnya Tuhanmu lebih mengetahui yang mana lebih enak ibu dengar perlu pakai Dia? tapi benar juga kalo saya tidak pakaikan dia? sesungguhnya tuhanmu Dia lebih mengetahui oke tapi di

\footnotetext{
${ }^{30}$ Muzayyin, "Resepsi Hermeneutika dalam Penafsiran al-Qur'an oleh M. Quraish Shihab: Upaya Negosiasi antara Hermeneutika dan Tafsir al-Qur'an untuk Menemukan Titik Persamaan dan Perbedaan”, h. 118.

${ }^{31}$ Lihat Ahmad Wajiz Zamany, "Syafa'ah dalam al-Qur'an (Studi Terhadap Penafsiran M. Quraish Shihab dalam Tafsir Al-Mishbah)", Skripsi UIN Sunan Kalijaga Yogyakarta, 2011, h. 27-28.
} 
sini dia pakai dia kenapa di sini dipakaikan Dia untuk menjelaskan bahwa tidak ada yang mengetahui kecuali Dia. ${ }^{32}$

Kehadiran pembahasan di atas, yang dalam hal ini tidak dijelaskan dalam penafsiran tulisan menjadikan penafsiran tersebut berdasarkan kenyamanan penafsir. Selain itu, berbagai penjelasan yang subordinatif ditemukan pada redaksi penjelasan di atas, di antaranya "Iqra' bismi rabbik di sini Inna rabbaka bukan dia katakan Innallah, Ya-ayyubal-muddas $|s|$ ir kum faanz| ir wa rabbaka..." ungkapan dari Iqra' bismi rabbik ke Inna rabbaka tidak memerhatikan aturan kalimat. Hal ini juga terjadi pada Innallaha, Ya ayyuhal-muddas $|s| i r$, yang Quraish Shihab juga tidak memerhatikan aturan ungkapan kalimat dari Innallaha ke Ya-ayyubalmuddas $|s|$ ir. Lebih jauh, ungkapan yang bercirikan subordinatif juga ditemukan pada:

Kalau al-Qur'an sejak semula berkata Iqra' bismillah bacalah dengan nama Allah, mereka berkata saya juga kan baca dengan nama Allah, tidak! baca dengan nama Tuhanmu! bukan Tuhan yang mereka sembah!. ${ }^{33}$

Keberadaan Aditif pada ungkapan di atas terdapat pada ketidakadanya aturan kalimat yang diikuti oleh Quraish Shihab saat mengatakan “...bismillab” ke "bacalah”, “...Allah” ke "mereka".

2) Penafsiran QS. al-Qalam Ayat 8-16

Kata waddu (ayat 9) tidak dijelaskan pada penafsiran tulisan, tetapi Quraish Shihab menjelaskannya pada penafsiran lisan. Hal ini sebagaimana diuraikannya sebagai berikut:

Waddu itu apa artinya? kita biasa dengar mawaddah, mawaddah itu dari kata waddu, mawaddah itu orang biasa diartikan suka cinta, bukan itu. Cinta plus waddu itu mawaddah itu adalah kesenangan yang luar biasa yang nampak tanda-tandanya dalam kenyataan, ada biasa orang cinta gombal nggak, nggak nampak tandanya, iya? itu juga tetapi kalau mawaddah, wud itu cinta yang menggebuh dan nampak, iya, memang dia cinta itu waddu oke di sini dia katakan waddu mereka itu sebenarnya ingin sekali dan sudah menampakkan tanda-tanda keinginannya untuk apa tudhinun.

Upaya penghubungan makna kata yang aditif (berdasarkan kenyamanan penutur) ini disebabkan kata mawaddah telah dikenal akrab oleh audiens, hal ini terlihat pada pernyataan Quraish Shihab yakni "Kita biasa dengar mawaddah".

Pada ayat 13, yakni pada kata Zanim oleh Quraish Shihab dijelaskan secara berbeda dari yang dijelaskan dalam penafsiran tulisan dengan peafsiran lisan. Pada penafsiran tulisan, Quraish Shihab membagi kelompok orang yang memahami makna zanim menjadi dua bagian, yakni pertama, zanim sebagai tanda atas seseorang yang terkenal karena keburukannya. Kedua, zanim sebagai anak haram. Mengenai pemahaman atas anak haram tersebut muncul beberapa nama, yakni al-Walid Ibn al-Mughirah, Abu Jahl Ibn Hisyam, al-Akhnas Ibnu Syuraiq, serta al-Aswad Ibn Abd Yaghuts. ${ }^{34}$

Sementara dalam penafsiran lisannya, Quraish Shihab langsung mengarahkan pembahasan ranim kepada cerita tentang al-Walid ibn Mughirah. Hal ini sebagaimana diuraikannya:

Zanim, ibu-ibu biasa lihat kambing dia punya telinga menjulur ke bawah yang menjulur ke bawah itu tempat giwan ini itu namanya zanim, nah ini sebenarnya sesuatu yang berlebih dari kata ini lantas diartikan seorang yang dinisbatkan kepada yang bukan ayahnya, artinya anak haram dia zanim. Ayat ini oleh sementara ulama dikatakan turun menyangkut seorang yang bernama Al-Walid Ibn Mughira, Al-Walid ini orang yang kaya raya tetapi dia sangat membenci Nabi, maka turun ayat-ayat ini menegur

\footnotetext{
${ }^{32}$ Video rekaman Quraish Shihab tentang penafsiran surah al-Qalam ayat 01-07, dalam "Kajian Tafsir AlMishbah" di Metro TV, pada 10 Oktober 2005. Menit 19:15-21:49.

${ }^{33}$ Video rekaman Quraish Shihab tentang penafsiran surah al-Qalam ayat 01-07, dalam "Kajian Tafsir AlMishbah" di Metro TV, pada 10 Oktober 2005. Menit 20:09-20:22.

${ }^{34}$ M. Quraish Shihab, Tafsir Al-Mishbah: Pesan, Kesan, dan Keserasian al-Qur'an, Vol XIV, h. 385.
} 
mengingatkan Nabi jangan patuh kepadanya sambil mengatakan itu orang orang jahat waktu turunnya ayat ini anak ini orang ini sudah jadi tokoh berkata "saya dituduh oleh al-Qur'an anak haram". Maka dia pergi mengancam ibunya "Ibu terus terang ibu, saya ini anak siapa?" ibunya mengaku bahwa memang pernah berselingkuh dan lahirlah kamu." $" 35$

Pengungkapan beberapa nama dalam penafsiran tulisan, menunjukkan penjelasan Quraish Shihab bersifat Subordinatif, hal ini karena ia memerhatikan makna-makna kata yang telah ada sebelumnya. Berbeda dengan penafsiran tulisannya, Quraish Shihab termasuk menggunakan ciri kelisanan aditif, karena menjelaskan kandungan zanim berdasarkan kenyamanannya. Penjelasan yang berdasarkan kehendak penutur tersebut kemudian pengantarnya pada penjelasan panjang lebar mengenai kisah al-Walid. Lebih jauh, pengangkatan kisah al-Walid tersebut merupakan upaya Quraish Shihab dalam menjaga makna zanim sebagai anak haram, hal ini disebut konservatif atas pengetahuan yang telah ada.

3) Penafsiran QS. al-Qalam ayat 17-33

Bagian ini (17-33) merupakan ayat-ayat yang di dalamnya menceritakan sebuah kisah pemilik kebun. Mengenai kisah tersebut, Quraish Shihab berbeda menyebut hakikat kisah ini dalam penafsiran tulisan dengan penafsiran lisan. Pada penafsiran tulisan, Quraish Shihab mengarahkan kisahnya sebagai kisah yang pernah terjadi (nyata). Lebih jauh, Quraish Shihab menyatakan bahwa kisah tersebut telah dikenal oleh berbagai kalangan masyarakat Mekah saat itu. ${ }^{36}$ Pernyataan Quraish Shihab tentang kisah nyata sebagaimana pada penafsiran tulisan, merupakan ciri keaksaraan yang memerhatikan aturan kalimat (Subordinatif) yang dalam hal ini mengikuti penjelasannya pada ayat sebelumnya, yakni tentang adanya keserupaan tentang beberapa sifat-sifat buruk dari uraian ayat 8 dan seterusnya.

Sementara dalam penafsiran lisan, Quraish Shihab mengkategorikan kisah ini sebagai kisah simbolik dan kisah nyata. Hal ini sebagaimana dalam uraiannya:

Berbeda pendapat ulama menyangkut kisah yang akan diuraikan ini apakah kisah yang benar-benar terjadi di suatu tempat ataukah dia itu kisah simbolik yang tentu kalau kisah simbolik mengandung makna-makna tertentu. ${ }^{37}$

Perubahan status kisah dari tulisan ke lisan tersebut, menjadikan penjelasan lisan Quraish Shihab sebagai Aditif, yakni mengemukakan pandangan berdasarkan kenyamanannya. Lebih jauh, penguraian kisah menjadi dua kategori dilakukan sebagai pengantar dalam menganalisis kisah tersebut. Pada ayat wala yastas $\backslash$ nun (ayat 18), Quraish Shihab mengurai persoalan Insya Allah. Hal ini sebagaimana dalam uraiannya sebagai berikut:

Saya ingin garis bawahi pelajaran insya Allah ini apalagi kita dalam masyarakat biasa berkata oke deh besok insya Allah saya datang, nda usah pake insya Allah dong. Seakan-akan insya Allab itu, nah tidak ada sesuatu yang terjadi yang hanya ditentukan oleh seorang anda berkata besok kita ketemu jam sepeluh, saya sudah mau ketemu jam sepeluh mau naik mobil kempes bannya, mau keluar saya sakit, mau keluar ada tamu dtang, keluar di jalan ada demo, banyak hal. Kalau begitu saya hanya salah satu faktor tapi masih banyak faktor lain yang harus berkumpul untuk sampainya apa yang anda kehendaki, yang bisa menghimpun semua faktor hanya Tuhan, karena itu anda harus berkata "kalau Dia berkehdak" kalau Dia tidak mau menghimpun semua faktor itu tidak bisa jadi, itu sebabnya kita dianjurkan berkata Insya Allah.

\footnotetext{
${ }^{35}$ Video rekaman Quraish Shihab tentang penafsiran surah al-Qalam 08-16, dalam "Kajian Tafsir Al-Mishbah" di Metro TV, pada 11 Oktober 2005. Menit 17:14-18:56.

${ }^{36}$ M. Quraish Shihab, Tafsir Al-Mishbah: Pesan, Kesan, dan Keserasian al-Qur'an, Vol XIV, h. 387.

${ }^{37}$ Video rekaman Quraish Shihab tentang penafsiran surah al-Qalam 17-32, dalam "Kajian Tafsir Al-Mishbah" di Metro TV, pada 14 Oktober 2005. Menit 01:51-02:14.
} 
Penjelasan yang panjang lebar mengenai insya Allah ini merupakan penjelasan yang Aditif. Hal ini disebabkan penjelasan Quraish Shihab di atas tidak sesuai dengan konteks ayat yang dijelaskannya, sekalipun melalui penjelasan tersebut kandungan kisah yang diuraikannya menjadi jelas. Ciri kelisanan lainnya yang muncul dalam penjelasan Insya Allah di atas adalah penjelasan yang dekat dengan kehidupan manusia sehari-hari, hal ini ditemukan pada pernyataan Quraish Shihab "Anda berkata besok kita ketemu jam sepeluh, saya sudah mau ketemu jam sepeluh mau naik mobil kempes bannya, mau keluar saya sakit, mau keluar ada tamu datang, keluar di jalan ada demo, banyak hal." Penjelasan 'rencana bertemu' tersebut juga merupakan bentuk analisis mendalam mengenai pentingnya mengucapkan Insya Allah. Lebih jauh, upaya analisis tentang kandungan Insya Allah nampak pada perkataan Quraish Shihab pada "Tidak ada sesuatu yang terjadi yang hanya ditentukan oleh seorang" dan "Yang bisa menghimpun semua faktor hanya Tuhan".

4) Penafsiran QS. al-Qalam ayat 44-52

Ayat kasabibil-but (ayat 48) yang merujuk kepada Nabi Yunus, oleh Quraish Shihab diceritakan pada penafsiran lisan, namun tidak pada penafsiran tulisan. Dalam penafsiran tulisan, Quraish Shihab hanya menggambarkan secara umum mengenai Nabi Yunus, yakni sebaga Nabi yang pernah marah karena ajakannya untuk beriman kepada Allah ditolak oleh umatnya. Disebabkan marah, Nabi Yunus pergi dan akhirnya ia ditelan oleh ikan. ${ }^{38}$ Penjelasan yang singkat tentang Nabi Yunus tersebut disebabkan ayatnya yang tidak banyak menjelaskan kisah Nabi Yunus, di sini Quraish Shihab memerhatikan struktur kalimat atau dikenal sebagai Subordinatif. Lebih jauh, menyangkut kisah Nabi Yunus yang lebih lengkap, Quraish Shihab menyarankan kepadan pembacanya untuk merujuk kepada QS. ash-Shaffat: $139-148 .^{39}$

Kata layugliquna (ayat 51) pada penafsiran tulisan Quraish Shihab, dijelaskan sisi kebahasaan dan dibaginya menjadi layuఇliqunaka dan layąliqunaka. Lebih jauh, kata layuəliquna berasal dari kata iəlaqa-yuશliqu yakni tergelincir akibat licin yang menyebabkan adanya kejatuhan, sehingga- lanjut Quraish Shihab- kata tersebut diartikan sebagai menjatubkan. Adapun makna layazliqunaka berasal dari kata zaliqa yang berarti memindabkan dari tempat. Dari sini- jelas Quraish Shihab- orang-orang kafir hendak menjauhkan Nabi Muhammad dari dakwah yang diajarkannya kepada umat manusia.

Penjelasan kebahasaan Quraish Shihab tersebut di atas mengantarnya menjadi ciri keaksaraan yang dalam hal ini disebut Subordinatif, yakni memerhatikan bentuk-bentuk kalimat (makna). Sementara dalam penafsiran lisan, Quraish Shihab membawa penjelasan tentang layuðliqunaka ke dalam pembahasan kontekstual, yakni konteks Indonesia (Jakarta), hal ini sebagaimana diuraikannya:

Ada orang yang matanya tajam bisa mengakibatkan orang sakit, saya kira kita di Indonesia di Jakarta ini bilang 'amit-amit' yah, itu karena katanya matanya berbisa nah ini hampir saja mereka itu mencelakakan kamu dengan matanya.

Kata "ini”" dalam penjelasan Quraish Shihab di atas merupakan bentuk aditif yang tidak memerhatikan struktur kalimat.

\section{Persamaan Penafsiran Tulisan dan Lisan}

\section{Penafsiran QS. al-Qalam ayat 1-7}

Kata qalam dalam penafsiran tulisan dan lisan Quraish Shihab diartikan sebagai alat tulis. Pada penafsiran tulisan, Quraish Shihab menyatakan bahwa terdapat pemahaman sempit dan umam tentang qalam, yakni dalam arti sempit berarti pena tertentu, dan dalam arti luas berarti semua bentuk alat tulis. Lebih jauh, Quraish Shihab cenderung memahami

\footnotetext{
${ }^{38}$ Lihat M. Quraish Shihab, Tafsir Al-Mishbah: Pesan, Kesan, dan Keserasian al-Qur'an, Vol XIV, h. 401.

${ }^{39}$ M. Quraish Shihab, Tafsir Al-Mishbah: Pesan, Kesan, dan Keserasian al-Qur'an, Vol XIV, h. 401.
} 
qalam tersebut atas semua bentuk alat tulis, hal ini disebabkan sesuai dengan tradisi membaca yang diperintahkan dalam surah al-'Alaq (sebagai wahyu sebelum al-Qalam). ${ }^{40}$

Adapun dalam penafsiran lisan, penjelasan tentang qalam sebagai pena dapat diketahui sebagai berikut:

Saya terangkan duluh apa artinya qalam itu qalam itu kalau dari segi bahasa berarti memotong memotong kuku taqli>mu az\}afir dulu orang menggunakan alat tulis itu apa toh? lidih atau apa yang dipotong ujungnya karena itu alat tulis dinamai qalam. Ada ulama berkata bahwa tapi ini pendapat lemah tapi saya kemukakan karena ada pendapat seperti ini yang pertama yang diciptakan pena pena itulah yang menulis semua takdir Tuhan ou ini si A begini ini si B begini ini si C begini ini begini itu semua tertulis oleh pena itu saya katakan pendapat ini lemah pendapat yang lebih bagus adalah alat tulis. ${ }^{41}$

Ungkapan "tapi ini pendapat lemah tapi saya kemukakan karena ada pendapat seperti ini" merupakan ungkapan yang disampaikan berdasarkan kenyamanan penutur, dan tidak memerhatikan aturan kalimat, dalam hal ini disebut Aditif.

Pada ayat tentang keagungan akhlak Nabi (ayat 4), baik pada penafsiran tulisan maupaun lisan, Quraish Shihab mengurainya dengan lengkap atas setiap huruh/kata yang termuat di dalamnya. Pada penafsiran tulisan Quraish Shihab menyatakan bahwa:

Keluhuran budi pekerti Nabi saw. Yang mencapai puncaknya itu bukan saja dilukiskan oleh ayat di atas dengan kata innaka/sesunggubnya engkau, tetapi juga dengan tanwin (bunyi dengung) pada kata khuluqin dan huruf lam yang digunakan untuk mengukuhkan kandungan pesan yang menghiasi kata 'ala, disamping kata 'ala tu sendiri, sehingga berbunyi la'ala, dan yang terakhir pada ayat ini adalah penyifatan khuluq itu oleh Tuhan Yang Maha Agung dengan kata 'azim/agung.

Adapun dalam penafsiran lisan Quraish Shihab mengatakan:

wa innaka la'ala $>$ khuluqin az\} hi $>m$ dan sesungguhnya engkau sungguh berada di atas akhlak yang mulia. Kita lihat ini yah di sini ingin digambarkan betapa mulianya akhlak Nabi Muhammad, kalau saya berkata begini e dia datang yang mana lebih kuat penekanannya kata dia datang atau sesungguhnya dia datang? di sini dia katakan innaka sesungguhnya engkau, baru itu kata inna la la itu artinya sungguh aku bersumpah, yang mana lebih kuat kata sesungguhnya dia datang atau saya berkata sesungguhnya sungguh saya bersumpah dia datang? sudah dua, yang mana lebih tinggi maknanya dia berada atau dia di atas? innaka laala di atas, jadi orang lain itu akhlaknya biasa-biasa saja, tapi engkau berada di atas khuluqin itu dalam bahasa al-Qur'an kalau ada tanwin en ajrin ajrun gafurun itu antara lain menunjukkan keagungan, jadi khuluqin apa artinya? akhlak yang agung bukan akhlak, ini baru azim agung besar, kalau anak kecil berkata berat itu benar berat atau tidak? berat buat dia buat ibu tidak, tapi kalau ibu berkata berat itu anak kecil wooo beratnya luar biasa, kalau Tuhan berkata agung? jadi itu kamu berada di atas akhlak yang agung itu tidak bisa dibayangkan lagi engkau wahai muhammad berada di atas sungguh berada di atas akhlak yang akhlak yang sangat agung.

Pada penafsiran tulisan di atas penjelasan Quraish Shihab, dilakukan dengan Subordinatif, yakni memerhatikan aturan kalimat yang hanya berfokus pada kaidah-kaidah kebahasaan (nabwu). Pada penafsiran lisan, menjelaskan kandungan ayat dengan Aditif, yakni menyampaikan makna kata berdasarkan kenyaman penulis. Lebih jauh, pemanfaat konteks

\footnotetext{
${ }^{40}$ M. Quraish Shihab, Tafsir Al-Mishbah: Pesan, Kesan, dan Keserasian al-Qur'an, Vol XIV, h. 379.

${ }^{41}$ Video rekaman Quraish Shihab tentang penafsiran surah al-Qalam ayat 01-07, dalam "Kajian Tafsir AlMishbah" di Metro'TV, pada 10 Oktober 2005. Menit 05:57-06:59.

${ }^{42}$ M. Quraish Shihab, Tafsir Al-Mishbah: Pesan, Kesan, dan Keserasian al-Qur'an, Vol. XIV, h. 381.
} 
keseharian (yakni pada ungkapan "saya datang", "anak kecil") memperjelas pemaparan Quraish Shihab yang lebih mementingkan kenyamanan dalam penjelasannya.

2. Penafsiran QS. al-Qalam ayat 8-16

Kata hammaz, (ayat 11) baik dalam penafsiran tulisan maupun lisan dijelaskan sebagai huruf hamzah, atau huruf yang keluar dari tenggorokan. Dalam penafsiran tulisan, Qurais Shihab mengutip bahwa kata hammaz berasal dari kata al-hamz, yang berarti dorongan. Keberadaan huruf tersebut di tenggorokan, menjadikannya ketika diucapkan harus melakukan dorongan atau tekanan. Dari sini -dalam penafsiran tulisan- kata tersebut kemudian berkembang hingga bermakna gibah. ${ }^{43}$ Pada penafsiran lisan, Quraish Shihab menyatakan:

Hammazin itu kata biasa sebut ha ba itu keluarnya dari tenggorakan dalam sini, kalau ha ha itu ditekan nafas ha ha rasanya ada? nah, hammaz, itu orang yang menekan dan menusuk dengan lidahnya atau dengan tangannya siapa itu? orang yang dinamakan orang yang menusuk dengan lidahnya yang menyebut-nyebut orang dibelakangnya menyangkut keburukannya mengumpat, iya toh? ou itu si A itu begini begini begini itu dalam bahasa agama ghiba, itu sebenarnya dia menusuk menusuknya dari belakang itu sebabnya dia disebut hammaz menusuk ghiba. ${ }^{44}$

Kata ba dan "begini" yang berulangkali diucapkan merupakan keberlebih-lebihan dari penjelasan Quraish Shihab. Sementara pertanyaan siapa itu? merupakan bentuk analitis yang digunakan untuk memperdalam penjelasan yang hendak disampaikan. Lebih jauh, penjelasan Quraish Shihab tersebut dilakukan mempraktekkan huruf ba (terlihat dengan penyebutan kata "di sini") merupakan upaya penjelasan yang dekat dengan audiens.

Kata al-Khair (ayat 12) baik dalam penafsiran tulisan maupun lisan, Quraish Shihab memakaninya kebajikan dan harta, dari sini Quraish Shihab baik dalam tulisan maupun lisan menekankan untuk memperoleh dan memaanfaatkan harta dengan baik. Pada penafsiran tulisan Quraish Shihab mengutip "Baca QS. al-Baqarah: [2] 180."45 pengutipan ini dilakukan karena pengartian harta sebagai agama terdapat pada surah tersebut.

3. Penafsiran QS. al-Qalam ayat 17-33

Ayat ayat 17-33 merupakan ayat yang membahas tentang kisah pemilik kebun, dalam hal ini baik penafsiran tulisan maupun lisan, Quraish Shihab mengungkap tentang ayah pemilik kebun yang sifatnya dermawan kepada fakir miskin, tetapi sifat tersebut tidak diteruskan oleh Anak-anaknya, surah ini menjelaskan tentang kisah anak-anak dari pemilik kebun tersebut. Quraish Shihab dalam penafsiran tulisannya mengatakan:

Sementara ulama menyebutkan bahwa pemilik-pemilik kebun adalah beberapa orang yang tinggal di satu tempat bernama Dharawan, yang berlokasi tidak jauh dari Shan'a di Yaman. Kebun itu berasal dari peninggalan orang tua mereka yang sangat shaleh. Orang tuanya bersedekah dari panen kebunnya kepada fakir miskin, bahkan membiarkan mereka ikut memetik, tetapi anak-anaknya tidak demikian. Mereka kikir walau salah seorang di antara mereka tidak terlalu kikir, tetapi pada akhirnya mereka pun bersepakat setelah didesak oleh yang saudaranya lain -sebagaimana diisyaratkan oleh sumpah yang direkam ayat di atas. Lalu terjadilah bencana yang diuraikan ayat di atas. ${ }^{46}$ Adapun dalam penafsiran lisan, Quraish Shihab menjelaskan:

Ada seorang tua tinggal ada yang berkata di Etopia ada yang berkata di Yaman dekat ibu kota Yaman sekarang San'a, itu orang yang shaleh punya anak banyak orang ini memiliki harta kekayaan dan kebun-kebun dan dia selalu menyisihkan hasil

\footnotetext{
${ }^{43}$ M. Quraish Shihab, Tafsir Al-Mishbah: Pesan, Kesan, dan Keserasian al-Qur'an, Vol. XIV, h. 384.

${ }^{44}$ Video rekaman Quraish Shihab tentang penafsiran surah al-Qalam ayat 08-16, dalam "Kajian Tafsir AlMishbah" di MetroTV, pada 11 Oktober 2005. Menit 12:11-13:02.

${ }^{45}$ M. Quraish Shihab, Tafsir Al-Mishbah: Pesan, Kesan, dan Keserasian al-Qur'an, Vol. XIV, h. 385.

${ }^{46} \mathrm{M}$. Quraish Shihab, Tafsir Al-Mishbah: Pesan, Kesan, dan Keserasian al-Qur'an, Vol. XIV, h. 387-388.
} 
panennya untuk fakir miskin bahkan membiarkan mereka itu masuk ke kebunnya memetik sekehendak hatinya. Tentu saja dia mewasiatkan anak-anaknya agar tradisinya ini dilanjutkan setelah kematiannya sang Ayah kemudian meninggal dunia kisah anakanaknya inilah yg diksahkan di sini.

Kata "ada" "itu" "dan" yang diungkapkan oleh Quraish Shihab di atas merupakan bentuk Aditif, hal ini karena tidak sesuai dan tidak memerhatikan aturan kalimat. Selain itu, ungkapan "...di Yaman dekat ibu kota Yaman sekarang San'a” merupakan penjelasan yang berlebihan tentang Yaman.

Kata tafa (ayat 19) dalam penafsiran tulisan dan lisan, Quraish Shihab merujuk makna kata tersebut dari kata tawaf, yang berarti keliling. Dari sini kemudian salah satu maknanya adalah bencana. Pada penafsiran tulisan, Quraish Shihab menyebutkan pendapat ulama yang mengatakan bahwa kata tafa hanya digunakan pada kejadian yang terjadi pada waktu malam. ${ }^{47}$ Pada penafsiran lisan, Quraish Shihab mengatakan:

Tafa itu seperti tawaf tawafitu apa? berkeliling taif itu artinya siksa, bencana, maka ada bencana yang datang dari Tuhanmu yang mengelililngi kebun itu. ${ }^{48}$

4. Penafsiran QS. al-Qalam ayat 34-43

Pada ayat 34 dikemukakan ganjaran berupa surga diperoleh oleh orang-orang yang bertaqwah. Quraish Shihab dalam hal ini mengemukakan perkataan kaum Musyrikin yang menyatakan dirinya sama atau bahkan melebihi ganjaran yang diperoleh kaum muslim. Pada penafsiran tulisan, Quraish Shihab mengatakan:

Sementara ulama menyatakan bahwa kaum musyrikin Mekkah berkata ketika mendengar ayat-ayat yang lalu bahwa: "Kami akan memperoleh yang lebih baik di akhirat nanti." $" 49$

Kutipan Quraish Shihab di atas merupakan bentuk Subordinatif, yakni memerehatikan aturan kalimat. Adapun dalam penafsiran lisan, Quraish Shihab mengatakan:

Orang-orang kafir ini merasa dirinya "saya dapat uang banyak saya dapat anak saya dapat kedudukan" mereka beranggapan itu tanda sayang Tuhan kepada mereka, lantas mereka berkata oh kamu bilang orang bertaqwa dapat surga di sisi Tuhan kami pasti sama bahkan kami lebih karena di dunia Tuhan sudah senang pada kami kami diberi harta kami diberi anak kami diberi kedudukan itu pasti kalau ada surga ada neraka kami dapat lebih bagus dari kamu. itu logika mereka itu logika yang salah karena pemberian harta pemberian kedudukan bukan tanda cinta Tuhan pada seseorang kemiskinan yang dialami seseorang setelah ia berupaya, sakit yang dialami seseorang setelah ia berupaya menghindar itu bukan tanda murka Tuhan. ${ }^{50}$

Dalam penjelasan di atas terlihat penjelasan tentang anak dan harta dan "saya dapat" yang diulang-ulang, sehingga perkataan tersebut mengandung unsur keberlebih-lebihan. Selain itu, penjelasan mengenai mendapatkan uang, anak, dan kedudukan adalah bentuk penjelasan yang dekat dari kehidupan audiens dan penutur, yang dapat ditemui sehari-hari, sehingga membantu pemahaman yang disampaikan Quraish Shihab. Selain mengulang-ulang kalimat "saya dapat" pada "saya dapat uang banyak saya dapat anak saya dapat kedudukan", ungkapan tersebut juga tidak mengikuti aturan kalimat (Aditif), yakni disampaikan berdasarkan kenyamanan penutur.

5. Penafsiran QS. al-Qalam ayat 44-52

\footnotetext{
${ }^{47}$ M. Quraish Shihab, Tafsir Al-Mishbah: Pesan, Kesan, dan Keserasian al-Qur'an, Vol. XIV, h. 388.

${ }^{48}$ Video rekaman Quraish Shihab tentang penafsiran surah al-Qalam ayat 17-33, dalam "Kajian Tafsir AlMishbah" MetroTV, pada 13 Oktober 2005. Menit 08:02-08:21.

${ }^{49}$ M. Quraish Shihab, Tafsir Al-Mishbah: Pesan, Kesan, dan Keserasian al-Qur'an, Vol. XIV, h. 393.

${ }^{50}$ Video rekaman Quraish Shihab tentang penafsiran surah al-Qalam ayat 33-43, dalam "Kajian Tafsir AlMishbah” MetroTV, pada 13 Oktober 2005. Menit 07:15-08:14.
} 
Kata faz\arni, sanastadrijubum, dan wa umli (lihat ayat 44-45) dijelaskan kandungan tentang penggunaan kata "Aku" dan "Kami" yang disandarkan oleh Allah, baik pada penafsiran tulisan maupun lisan. Pada penafsiran tulisan Quraish Shihab menyatakan bahwa:

Ayat di atas menggunakan bentuk jamak pada kata sanastadrijubum/Kami akan menarik mereka setahap demi tahap, tetapi menggunakan bentuk tunggal pada kata dan umli. Penggunaan bentuk jamak itu menunjukkan adanya banyak pihak/hal yang terlibat dalam penarikan tahap demi tahap menuju kebinasaan itu, sedang bentuk tunggal pada kata $z \backslash a r n i$ untuk memerintahkan agar tidak mengandalkan siapa pun selain Allah, sedang pada kata umli> untuk mengisyaratkan bahwa penangguhan dan pentahapan itu semata-mata atas ketetapan dan kehendak Allah, tidak ada campur tangan selain-Nya menyangkut waktu dan pentahapannya, termasuk waktu datangnya ajal mereka. ${ }^{51}$ Sementara dalam penafsiran lisan, Quraish Shihab menyatakan:

Ada hal yang menarik, coba kita perhatikan ayat kita ini yang pertama dia katakan faz \arni biarkan Aku Aku, tetapi waktu dia katakan selnjutnya sanastadrijubum Kami akan menarik dia tahap demi tahap yang pertama dia katakan Aku yang kedua dia katakan Kami, baru dia katakan lagi wa umli Saya beri tangguh. Jadi dua kali Aku sekali Kami, itu di dalam al-Qur'an biasanya sekali lagi biasanya kalau Tuhan menunjuk dirinya dengan kata Aku maka tidak ada yang lain yang terlibat kecuali Dia, itu sebabnya Dia katakan wa ani'budu>ni sembahlah Aku wa anattawwab saya yang memberi taubat, tidak ada yang lain tetapi kalau Dia menunjuk diri-Nya dengan kata Kami, maka itu ada pihak lain yang terlibat inna nabnu nazzalna z〉ikra Kami yang menurunkan al-Qur'an yang menurunkan al-Qur'an itu malaikat Jibril atau Tuhan? iya toh, jadi kalau Kami ada pihak lain ketika Allah akan menciptakan ada Dia berkata Aku yang menciptakannya ketika Allah menciptakan kita Allah berfirman laqad khalqna sesungguhnya Kami telah menciptakan karena kita tercipta dari ibu bapak kita, jadi ada keterlibatan. nah kalau begitu kita lihat di sini biarkan aku sendiri tidak usah harapkan orang lain, saya sendiri baru dia katakan sanastadrijubum Kami tarik dia tahap demi setahap, di sini akan ada sekian banyak pihak yang akan tarik dia tahap demi tahap boleh jadi temannya yang apa namanya yang bela-bela dia yang obok-obok dia ayo biar begini boleh jadi kekayaannya boleh jadi itu itu cara Tuhan baru dikatakan wa umli labum saya juga Saya punya kebijaksanaan kapan Saya tangguhkan dia, kapan saya jatuhkan orang itu karena itu kebijaksanaan saya sendiri.

Penjelasan di atas mengandung unsur berlebih-lebihan, hal ini terlihat pada kata yang seringkali diulangi, misalnya kata "biasanya skali lagi biasanya", "aku sendiri tidak usah harapkan orang lain, saya sendiri..”. Selain itu, penjelasan di atas juga mengandung aditif, hal ini terlihat pada perkataan "nah" dan "kapan" yang diungkapkan penutur. Selain itu, pertanyaan "yang menurunkan al-Qur'an itu malaikat Jibril atau Tuhan?” merupakan bentuk analisis untuk pemahaman tentang penggunaan kata "Kami". Lebih jauh, pada penjelasan mengenai makna penggunaan kata "Aku" di atas juga diperkuat dengan analisis pada uraiannya yang menyatakan "itu sebabnya Dia katakan wa ani'buduni sembahlah Aku wa anattawwab saya yang memberi taubat”.

\section{Faktor-Faktor Terjadinya Perbedaan dan Persamaan}

\section{Peran M. Quraish Shihab}

Sebagaimana yang dijelaskan pada bab biografi sebelumnya, dan bahkan yang telah dikenal secara luas bahwa Quraish Shihab merupakan penafsir yang terkenal pada era modern-kontemporer. Jika demikian, maka tugas utama Quraish Shihab adalah mengungkap kandungan al-Qur'an, hal ini tentu dilakukan dengan sungguh-sungguh dan renungan yang

\footnotetext{
${ }^{51}$ M. Quraish Shihab, Tafsir Al-Mishbah: Pesan, Kesan, dan Keserasian al-Qur'an, Vol. XIV, h. 398-99.
} 
dalam. ${ }^{52}$ Tetapi dalam penafsiran secara lisan, Quraish Shihab tidak berhenti hanya sebatas membuka makna saja, sebagaimana yang dilakukannya pada penafsirannya secara tulisan. Melainkan juga melakukan ajakan kepada audiens (pendengar) untuk 'memperhatikan' ajaran agama. Pengajakan tersebut di sini kemudian menjadikan sosok Quraish Shihab seketika berperan sebagai pendakwah, yakni mengajak dan menyeru manusia untuk mengikuti perintah-perintah Allah dan Rasul-Nya. ${ }^{53}$

2. Konteks Tulisan dan Lisan

Tidak bisa dipungkiri bahwa perbedaan konteks dapat menyebabkan adanya perbedaan penafsiran. Hal ini disebabkan seorang penafsir berusaha mendialogkan teks dengan konteks yang dihadapinya. Quraish Shihab ketika melakukan penafsiran dalam bentuk tulisan, ia mencoba mendialogkan teks dengan konteks modern-kontemporer secara umum (luas), yang menyebabkan pembaca akan mengira-ngira tentang konteks modernkontemporer yang bagaimana yang hendak digambarkan oleh Quraish Shihab. Hal ini berbeda dengan penafsiran lisannya, Quraish Shihab lebih menampilkan konteks yang jelas dan tengah dihadapi pada saat itu juga oleh penafsir dan audiens.

3. Teks (Al-Qur'an)

Menurut Quraish Shihahb bahwa munculnya perbedaan penafsiran di antaranya disebabkan oleh teks (al-Qur'an) itu sendiri, hal ini dalam al-Qur'an tidak dapat dipastikan suatu ayat bersifat mubkam atau mutasyabih, umum atau khusus, dan lain sebagainya. ${ }^{54}$ Berkenaan dengan ini, adanya 'kemungkinan-kemungkinan' dalam makna yang terkandung pada ayat atau kata dalam surah al-Qalam, menjadikan hasil pemahaman Quraish Shihab berbeda dari penafsiran tulisan dengan penafsiran lisannya. Ketidakjelasan atau kemungkinan-kemungkinan makna atas teks tersebut menggiring penafsir untuk memahaminya berdasarkan konteks, metode, dan pra-pemahaman yang dimiliki oleh penafsir.

4. Audiens (Pembaca dan Pendengar)

Audiens dalam penyampaian pemahaman atas kandungan al-Qur'an juga sangat memiliki peran yang signifikan. Dalam konteks ini, audiens yang dihadapi oleh penafsir berbeda ketika berada dalam lingkup tulisan dengan lingkup lisan. audiens yang hadir dalam lingkup tulisan merupakan hasil rekaan penafsir, sedangkan dalam lingkup lisan bersifat nyata. Akibatnya, pemahaman yang disampaikan dalam bentuk tulisan lebih bersifat umum dengan berdasar atas rekaan audien yang diciptakan penafsir, hal ini berbeda dengan pemahaman yang disampaikan dalam bentuk lisan yang lebih bersifat nyata, berdasarkan keadaan audiensnya.

\section{Faktor-Faktor yang Menyebabkan Persamaan}

\section{Konteks Kehidupan Penafsir}

Quraish Shihab merupakan penafsir pada masa modern-kontemporer, sehingga menjadikan penafsirannya senantiasa merespon persoalan-persoalan yang tengah dihadapinya. Hal ini terjadi baik dalam penafsiran tulisan maupun penafsiran lisan.

2. Format Penyajian Penafsiran

Sekalipun dalam penyampaiannya, Quraish Shihab memiliki peran ganda, yakni sebagai penafsir dan pendakwah. Tetapi dalam mengungkap kandungan surah al-Qalam, Quraish Shihab tidak lepas dari konsep muna>sabah-nya. Sehingga pemahaman yang diperlihatkannya tidak banyak berbeda antara penafsiran tulisan dengan penafsiran lisannya. Selain itu, metode penjelasan kosa kata secara mendalam juga tidak pernah ia tinggalkan, hal

\footnotetext{
${ }^{52}$ Abd. Rahman Dahlan, Kaidab-kaidah Penafsiran Al-Qur'an. (Bandung: Penerbit Mizan, 1997), h. 21.

${ }^{53}$ Saerozi, Imu Dakwah. (Yogyakarta: Ombak, 2013), h. 11.

${ }^{54}$ Rekaman video Sunni dan Syiah -Prof DR. Quraish Shihab, dipublikasikan tanggal 16 November 2013.
} 
ini disebabkan penyampaian makna kosakata telah menjadi struktur pemikiran tersendiri yang dimiliki oleh Quraish Shihab. Lebih jauh, dalam membantu pemahamannya, Quraish Shihab senantiasa merujuk kepada pemikiran dari ulama lainnya.

\section{Simpulan}

Melalui penafsiran tulisan dan lisannya, Quraish Shihab menjelaskan bahwa kandungan surah al-Qalam secara umum berisikan tentang Kebenaran. Penjelasannya mengantarkan atas upaya mencapainya, mempertahankanya, ganjaran bagi orang yang berada di dalam kebenaran itu, siksaan bagi orang yang melanggarnya, serta cara menanggapi orang yang mengabaikan ataupun menolak kebenaran tersebut. Sehingga Penafsiran lisan (dalam kajian tafsir Al-Misbah) Quraish Shihab memberikan wajah baru terhadap penafsiran yang telah ada dalam bentuk tulisan (dalam kitab tafsir Al-Misbah).

Pembacaan dengan menggunakan teori kelisanan, khususnya ciri aditif alib-alib subordinatif dalam melihat (baca: menganalisis) penafsiran Quraish Shihab memberikan diskursus tersendiri, yang dalam hal ini menjadikan penafsiran Quraish Shihab dapat dipetapetakan, dipilah, serta didudukkan mengenai hasil penafsiran Quraish Shihab, baik penafsiran tulisan apalagi penafsiran lisannya.

\section{Daftar Pustaka}

Dahlan, Abd. Rahman, (1997). Kaidah-Kaidah Penafsiran Al-Qur'an. Bandung: Penerbit Mizan. Federspiel, Howard M. (1996). Kajian Al-Qur'an di Indonesia, terj. Tajul Arifin. Bandung: Penerbit Mizan.

Goldziher, Ignaz, (2010). Mą̧̧ab Tafsir dari Klasik hingga Modern, terj. M. Alaika Salamullah, dkk,Yogyakarta: Penerbit eLSAQ Press.

Gusmian, Islah, (2003). Khazanah Tafsir Indonesia: dari Hermenentika bingga Ideologi, Jakarta: Teraju.

http://themuslim500.com. Diakses pada 28 September 2017.

Https://id.wikipedia.org/wiki/Muhammad_Quraish_Shihab. diakses pada 28 September 2017.

Ikhwan, Munirul, (2015). “An Indonesian Initiative to Make the Qur'an Down-to-Earth: Muhammad Quraish Shihab and His School of Exegesis", Dissertation, Universität Berlin, Berlin.

Kajian Tafsir Al-Mishbah Spesial Hilbram Dunar -Jusuf Kalla, MetroTV. Diakses pada 27 September 2017.

Masduki, Mahfudz, Tafsir Al-Mishbah M. Quraish Shibab: Kajian atas Amtsal al-Qur'an, (Yogyakarta: Pustaka Pelajar, 2012).

Mufid, Abd. (2012) "Perbandingan Kerajaan Allah menurut Stephen Tong dan Al-Mulk Menurut M. Quraish Shihab”, Skripsi UIN Sunan Kalijaga Yogyakarta.

Musbikin, Imam, (2014). "Mutiara" Al-Qur'an, khazanah Ilmu Tafsir dan Al-Qur'an, Madiun: Jaya Star Nine.

Mustaqim, Abdul, (2011) Pergeseran Epistemologi Tafsir, (Yogyakarta: PT LKiS Printing Cemerlang.

Muzayyin, (2015). Resepsi Hermeneutika Dalam Penafsiran Al-Qur'an Oleh M. Quraish Shihab: Upaya Negosiasi Antara Hermeneutika dan Tafsir al-Qur'anuntuk Menemukan Titik Persamaan dan Perbedaan, dalam jurnal NUN edisi 1 No 1. Diterbitkan oleh Asosiasi Ilmu Al-Qur'an dan Tafsir se-Indonesia (AIAT).

Ong, Walter J., (2013). Kelisanan dan Keaksaan, terj. Rika Iffati, Yogyakarta: Penerbit Gading. R, Muaddibi Asfiyak, (2017)."Hermeneutika Al-Qur'an M. Quraish Shihab dalam Tafsir AlMishbah”, Skripsi UIN Sunan Kalijaga Yogyakarta.

Raditya, Ardhie, (2014). Sosiologi Tubub: Membentang Teori di Ranah Aplikasi, Yogyakarta: Kaukaba Dipantara. 
Saerozi, (2013). Imu Dakwah, Yogyakarta: Ombak..

Shihab, M. Quraish, (2015). Kaidah Tafsir, Tangerang: Penerbit Lentera Hati. ,(1995). Membumikan al-Qur'an: Fungsi dan Peran Wabyu dalam Kebidupan Masyarakat, Bandung: Penerbit Mizan ,(2011). Membumikan al-Qur'an: Memfungsikan Wabyu dalam Kebidupan, Tangerang: Lentera Hati. ,(2013). Secercab Cabaya Ilabi: Hidup Bersama Al-Qur'an, Bandung: Penerbit Misan. ,Wawasan al-Qur'an: Tafsir Maudbui atas Pelbagai Persoalan Umat, (Bandung: Penerbit Mizan, 1996).

Sidik, Muhammad Yusuf, (2016). "Penafsiran Ayat-ayat yang Dimaknai Hubungan Seksual Suami Istri menurut M. Quraish Shihab dalam Tafsir Al-Mishbah", Skripsi UIN Sunan Kalijaga.

Video rekaman "Highlight Mata Najwa: Cerita Dua Sahabat- Bagian 2". MetroTVnews. Pada 29 Juni 2017.

Video rekaman "Shihab dan Shihab" episode kedua, dipublikasikan oleh Roney 118 pada tanggal 29 Juni 2017.

Video rekaman Quraish Shihab tentang penafsiran surah al-Qalam 08-16, dalam "Kajian Tafsir Al-Mishbah" di Metro TV, pada 10-14 Oktober 2005.

Video Rekaman Sunni dan Syiah -Prof DR. Quraish Shihab, dipublikasikan tanggal 16 November 2013.

Zamany, Ahmad Wajiz, (2011). "Syafa'ah dalam al-Qur'an (Studi Terhadap Penafsiran M. Quraish Shihab dalam Tafsir Al-Mishbah)", Skripsi UIN Sunan Kalijaga Yogyakarta. 